\title{
Clinical sequelae from overfeeding in enterally fed critically ill adults: \\ Where is the evidence?
}

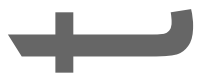

Manuscript

Authors

Chapple $L S^{1,2}$, Weinel $L^{1,2}$, Ridley $E J^{3,4}$, Jones $D^{5,6}$, Chapman $\mathrm{MJ}^{1,2}$, Peake $S^{2,7}$

Affiliations

${ }^{1}$ Intensive Care Research, Royal Adelaide Hospital, Adelaide 5000, Australia

${ }^{2}$ Discipline of Acute Care Medicine, School of Medicine, University of Adelaide, Adelaide 5000, Australia

${ }^{3}$ Australaian and New Zealand Intensive Care Research Centre, School of Public Health and Preventative Medicine, Monash University Melbourne 3004, Australia

${ }^{4}$ Nutrition Department, Alfred Health, Melbourne 3004, Australia

${ }^{5}$ Intensive Care Unit, Austin Health, Melbourne 3084, Australia

${ }^{6}$ School of Public Health and Preventive Medicine, Monash University Melbourne 3004, Australia

${ }^{7}$ Department of Intensive Care Medicine, The Queen Elizabeth Hospital, Adelaide 5011, Australia

\section{Corresponding author}

Dr Lee-anne Chapple

Email: lee-anne.chapple@adelaide.edu.au

Phone: +61870741763

Postal address: ICU Research, Desk 40, 4G751, Royal Adelaide Hospital, Port Road, Adelaide 5000,

Australia

Contact details:

Dr Lee-anne Chapple

PhD MNutDiet BMedSc

Intensive Gare Research

Royal Adelaide Hospital, Port Road, Adelaide

Email: lee-anne.chapple@adelaide.edu.au

Mr Luke Weinel

Research Scientist

Intensive Care Research

This is the author manuscript accepted for publication and has undergone full peer review but has not been through the copyediting, typesetting, pagination and proofreading process, which may lead to differences between this version and the Version of Record. Please cite this article as doi:

10.1002/jpen. 1740 .

This article is protected by copyright. All rights reserved. 
Royal Adelaide Hospital, Port Road, Adelaide

Email: luke.weinel@sa.gov.au

\section{Dr Emma Ridley}

Senior Research Fellow \& Lead, Nutrition Program, ANZIC-RC

Senior Dietitian, Intensive Care, The Alfred Hospital, Melbourne

Email: emma.ridley@monash.edu

\section{Associate Professor Daryl Jones}

BSc(Hons) MBBS FRACP FCICM MD PhD

A/Prof ANZIC-RC, Monash University

ICU Consultant, Austin Health

Email: daryl.jones@austin.org.au

\section{Professor Marianne Chapman}

MBBS, PhD,FJFICM, FANZCA

Director of Research, Intensive Care Unit

Royal Adelaide Hospital, Port Road, Adelaide

Email: marianne.chapman@sa.gov.au

\section{Professor Sandra Peake}

BM BS, BSc(Hons) FCICM, PhD

Director, Intensive Care Unit

The Queen Elizabeth Hospital, Woodville Road, Woodville, Adelaide

Email: sandra.peake@sa.gov.au

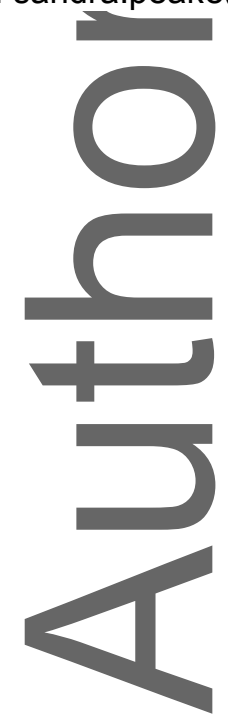

This article is protected by copyright. All rights reserved. 


\section{ABSTRACT}

Enteral calorie delivery in excess of requirements (overfeeding) is believed to cause adverse effects during critical illness, but the literature supporting this is limited. We aimed to quantify the reported frequency and clinical sequelae of calorie overfeeding with enterally-delivered nutrition in critically ill adult patients. A systematic search of MEDLINE, EMBASE, and CINAHL from conception to November 28, 2018 was conducted to identify clinical studies of nutrition interventions in enterally-fed critically ill adults that reported overfeeding in one or more study arms. Overfeeding was defined as calorie delivery $>2000 \mathrm{kcal}$ per day, $>25 \mathrm{kcal} / \mathrm{kg}$ per day, or $\geq 110 \%$ of calorie prescription. Data were extracted on methodology, demographics, prescribed and delivered nutrition, clinical variables and pre-defined gutcomes. Cochrane 'Risk of Bias' tool was used to assess the quality of RCTs. Eighteen studies were included; of which 10 were randomized ( $n=4386$ patients) and 8 were non-randomized $(n=223)$. Only 4 studies reported a separation in calorie delivery between treatment groups whereby one arm met the definition of overfeeding, for which no between-group differences in mortality, infectious complications or ventilatory support were reported. Overfeeding was associated with increased insulin administration (median 3 [IQR: 0-41.8] vs 0 [0-30.6] units/day) and upper gastrointestinal intolerance in one large RCT, and duration of antimicrobial therapy in a small RCT. There is limited high quality data to determine the impact of calorie overfeeding of critically ill patients by the enteral route; however, based on available evidence, does not appear to increase mortality or affect other important clinical outcomes.

\section{Keywords}

Overfeeding, critical care, enteral nutrition, calories

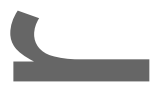

\section{INTRODUCTION}

Overfeeding, the provision of calories and protein in excess of metabolic requirements to critically ill patients, is thought to be associated with adverse clinical sequelae, including hyperglycemia, liver dysfunction, increased risk of infection, prolonged weaning from ventilatory support and increased mortality! - However, despite reported concerns, there is no universally agreed definition as to what constitutes calorie overfeeding or the clinical consequences. Moreover, the literature on overfeeding has predominantly been limited to calorie delivery via the parenteral, rather than enteral, route. ${ }^{2}$ In contrast to parenterally delivered nutrients, innate enteral control mechanisms may prevent or reduce the risk of overfeeding in the critically ill. Nutrient delivery to the small intestine initiates important feedback mechanisms that control gastric emptying. ${ }^{3}$ In health, nutrient emptying into the intestine occurs at a rate of $1-4 \mathrm{kcal} /$ minute. $^{4}$ In critical illness, the feedback mechanism is exaggerated and nutrient delivery to the small intestine can be markedly slowed. Gastrointestinal dysfunction is common and typically characterized by reduced gastric motility, ${ }^{5}$ and decreased absorption of both lipids and glucose.6,7 Enteral provision of nutrients during critical illness is preferred over the

This article is protected by copyright. All rights reserved. 
parenteral route, yet the frequency of enteral calorie overfeeding and how it may contribute to adverse outcomes in the critically ill is uncertain.

International critical care nutrition guidelines currently recommend a calorie goal of $20-25^{8}$ (European Society of Parenteral and Enteral Nutrition (ESPEN)) or 25-30 (American Society of Parenteral and Enteral Nutrition (ASPEN)) kcal/kg body weight/day. The avoidance of calorie overfeeding is also suggested, despite limited and low quality evidence to support this recommendation. ${ }^{8} 9$ Further, a consensus of what defines overfeeding is not available, and there is no distinction between overfeeding via the parenteral or enteral route. However, the ASPEN guidelines state that when enteral nutrition is adequate, the provision of supplemental parenteral nutrition should be reduced to avoid the complications associated with overfeeding. ${ }^{9}$

Given the lack of agreed definition for overfeeding associated with calorie delivery in the critically ill and the potential adverse outcomes, a systematic literature review was conducted to identify and quantify the frequency and clinical sequelae of documented enteral calorie overfeeding in critically ill MATERIALS AND METHODS

A systematic review of the literature was conducted in accordance with the principles outlined in the Preferred Reporting Items for Systematic Reviews and Meta-Analyses (PRISMA) statement ${ }^{10}$ and the protocol was prospectively registered with PROSPERO (CRD42018091648).

\section{Search strategy}

An electronic search to identify randomized and non-randomized studies using the Cochrane Central Register of Controlled Trials (CENTRAL), MEDLINE and EMBASE via OVID and CINAHL via EBSCOhost published from database inception to November 28, 2018. These databases were searched for studies using variations on the key words "intensive care" together with "enteral nutrition" and limited to human and adult studies. Only studies published in English were identified. The search strategies and MeSH headings are shown in Supplementary Tables S1-4.

\section{Study selection}

Duplicates were removed and titles and abstracts screened for eligibility (LW). Where relevance of the article was unclear from the abstract, the full text was obtained. Full texts were assessed against prespecified inclusion and exclusion criteria by two independent reviewers (LC and LW).

Studies conducted in adult critically ill patients ( $\geq 18$ years for all patients or where the mean or median age was $\geq 18$ years in all groups) were included. Critically ill patients were defined as patients

This article is protected by copyright. All rights reserved. 
recruited whilst present in an intensive care unit (ICU) and requiring invasive ventilation or where $>50 \%$ of the trial population required invasive mechanical ventilation. ${ }^{11}$

Studies were included if: 1) calorie delivery was via the enteral route (supplemental parenteral calories were permitted but were not a defined study intervention); 2) calorie prescription and delivery (in kcal per day or kcal/kg per day) or the percent of calories above prescription were reported or could be calculated from published data; 3 ) documented or calculated calorie delivery from one or more patient cohorts met one or more of our study definitions for overfeeding and; 4) at least one predefined clinical outcome including mortality, ventilator-free days, or infectious complications was reported (for a list of the pre-defined clinical outcomes see Supplementary Table S5). Only data published in the primary manuscript and supplementary materials were included.

For the purposes of this review, overfeeding was defined apriori as delivery of $>25 \mathrm{kcal} / \mathrm{kg}$ per day or $>2000 \mathrm{kcal}$ per day or $\geq 110 \%$ of calorie prescription. This definition was irrespective of the method (e.g. indirect calorimetry, fixed equation) or body weight (e.g. actual, ideal) used to determine calorie prescription and delivery. Calorie prescription $>25 \mathrm{kcal} / \mathrm{kg}$ per day exceeds the ESPEN recommendations of 20-25 kcal/kg per day and equates to $>2000 \mathrm{kcal}$ per day assuming an actual body weight of $80 \mathrm{~kg}$; the average weight of a critically ill patient receiving invasive mechanical ventilation. $8,9,12$ A sensitivity analysis was conducted including only those-Data were also reported separately for studies where $>30 \mathrm{kcal} / \mathrm{kg}$ per day was received, as this is the upper calorie recommendation according to the ASPEN guidelines. ${ }^{9}$ Finally, calorie administration of $\geq 110 \%$ above the defined target is consistent with the definition provided in the ESPEN guidelines for overfeeding. ${ }^{8}$

Studies were excluded if: 1) data on calorie delivery was not provided; 2) oral nutrition, animals or children were included; 3) no pre-defined clinical outcomes were reported; or 4) they were case reports, editorials, or reviews.

\section{Data extraction and quality assessment}

Data were independently extracted in duplicate (LW and also by LC or ER or DJ) using pre-defined data extraction forms. Discrepancies in data extraction were resolved by consensus.

Extracted data were: 1) study methodology i.e. study design, aim, intervention, population; 2) patient characteristics i.e. age, sex, injury severity of illness, weight, body mass index (BMI); 3) nutrition therapy prescribed and delivered; 4) patient outcomes i.e. mortality, duration of stay, organ support, respiratory parameters, infectious complications, blood glucose control, and other clinical complications (Supplementary Table S5).

Data presented in median and range/interquartile range were converted to mean (standard deviation) as per methodology by Wan and colleagues. ${ }^{13}$ Only papers in which relevant data were reported under each heading were presented in the tables.

This article is protected by copyright. All rights reserved. 


\section{Statistical analyses:}

'A sensitivity analysis was conducted for the four studies that reported differences in calorie delivery, where only one group met a criterium for overfeeding. The two types of studies, observational and randomised controlled trial, were combined using the principled method of Bayesian evidence synthesis $^{14^{-}}$via the "bayesmeta" package (https://cran.rproject.org/web/packages/bayesmeta/index.html) in the $\mathrm{R}$ statistical environment. Estimates were reported as (median) odds ratio and $95 \%$ credible intervals (Crl).'

\section{Risk of bias}

Risk of bias of individual studies was only assessed for randomized trials and completed in duplicate (LW and also by LC or ER or DJ) using the Cochrane 'Risk of Bias' tool which classifies risk as 'low', 'some concerns', or 'high'. Disagreements in risk of bias were resolved by discussion.

Assessment of publication bias using a funnel plot created in Review Manager 5 (RevMan5) ${ }^{15}$ was planned if more than 10 papers were identified that reported mortality as a dichotomous outcome. ${ }^{16}$

\section{RESULTS}

The database search identified a total of 5373 articles. After removing duplicates, 4481 unique articles remained. Title and abstract screening led to the retrieval of 140 full text articles for potential inclusion. Of these, 122 articles were excluded, with 18 studies eligible for inclusion in the final review (Figure 1).

Only four of the included studies (two randomized ${ }^{12,17}$ and two non-randomized ${ }^{18,}{ }^{19}$ ) reported a separation in calorie delivery between treatment groups in which one arm, and not the other, met the definition of overfeeding. In all of these trials, the definition of overfeeding met was $>25 \mathrm{kcal} / \mathrm{kg}$ per day. In only two of these studies were patients fed $>27 \mathrm{kcal} / \mathrm{kg}$ per day ${ }^{12,17}$.

The included studies consisted of 10 randomized parallel-arm trials (4386 patients), ${ }^{12,17,20-27}$ and eight non-randomized studies (223 patients) of which three were before-after studies, ${ }^{19,}{ }^{28-30}$ three prospective observational studies, ${ }^{31-33}$ one prospective cross-over trial, ${ }^{30}$ and one retrospective observational study ${ }^{18}$ (Table 1). In three of the non-randomized studies, there was no comparator group. ${ }^{31-33}$ The total number of patients included was 4609 and ranged from 5 to 3957.

\section{Trial characteristies}

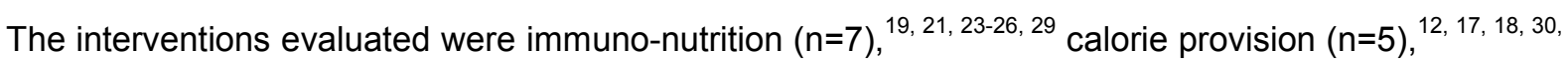
${ }^{32}$ macronutrient composition $(n=3),{ }^{20,22,} 28$ timing of enteral feeding $(n=1),{ }^{31}$ micronutrient provision $(n=1)^{27}$ and insulin therapy $\left(n=1\right.$, a post-hoc analysis of a previously reported trial). ${ }^{33}$ One immuno-

This article is protected by copyright. All rights reserved. 
nutrition study reported burns and trauma sub-groups separately. Only the burns sub-group met an overfeeding criterium and was included in this review. ${ }^{19}$

\section{Patient characteristics}

Overall, the patient populations were young and the majority of studies included more males than females (Table 1). Body mass index (BMI) was only reported in three randomized trials ${ }^{12,17,26}$ and two non-randomized studies. ${ }^{18,19}$ Only one randomized trial reported a BMI in the healthy weight range ${ }^{26}$ according to the World Health Organization classification. ${ }^{34}$

\section{Calorie prescription}

A fixed, weight-based equation was used to determine the feeding rate in 11 of the 18 included studies $(61 \%)$, of which seven were randomized trials ${ }^{12,17,21,23,24,26,27}$ and four were non-randomized studies $^{18,19,28,29}$ (Table 2). Calorie prescription was 25-35 kcal/kg per day in six of these studies (four randomized, two non-randomized) $)^{21,23,24,27,28,29}$ and $1 \mathrm{ml} / \mathrm{kg} /$ hour in two randomized studies. ${ }^{12,}{ }^{17}$ The fixed, weight-based equation used to determine calorie prescription was not reported in the remaining three studies. ${ }^{26,18,19}$

A predictive equation was applied in another five of the 18 included studies (28\%), including two randomized and three non-randomized studies: ${ }^{22,25,31-33}$ (Harris-Benedict, $\mathrm{n}=2 ;^{31,32}$ Scholfield, $\mathrm{n}=1{ }^{22}$ Curreri, $n=1 ;{ }^{25}$ Carlson and Milner, $n=1^{33}$ ). Three studies reported using a combination of fixed weightbased or predictive equation with indirect calorimetry ${ }^{25,27,33}$ and one of the 18 included studies reported using indirect calorimetry alone to determine calorie prescription. ${ }^{30}$ Finally, one nonrandomized study did not report the method for determining calorie prescription. ${ }^{20}$

\section{Calorie delivery}

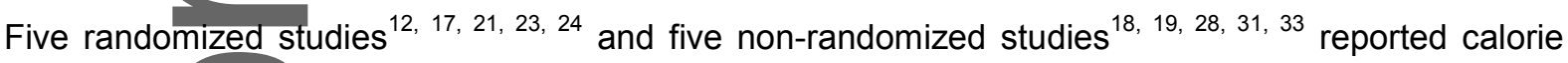
delivery $>25 \mathrm{kcal} / \mathrm{kg}$ per day (Table 2). Of these, four reported delivery $>30 \mathrm{kcal} / \mathrm{kg}$ per day. ${ }^{12,28,31,33}$ Calorie delivery $>2000 \mathrm{kcal}$ per day was reported in seven randomized ${ }^{12,20,22,24-27}$ and five nonrandomized $^{19,29,30,32,33}$ studies. Four of the included studies met both the overfeeding criteria for both total calories and $>25 \mathrm{kcal} / \mathrm{kg}$ per day. ${ }^{12,19,24,33}$ The mean duration of feeding ranged from 4 to 13 days in six randomized trials ${ }^{12,17,21,22,24,26}$, and 8 to 31 days in four non-randomized trials. ${ }^{18,28,29,31}$ Four randomized ${ }^{20,23,25,27}$ and four non-randomized ${ }^{19,30,32,33}$ studies did not report the duration of enteral feeding.

\section{Outcomes}

Mortality at one or more time-points was reported in 12 of the 18 included studies (67\%), of which six were randomized trials ${ }^{12,17,21,24-26}$ and six were non-randomized studies ${ }^{18,19,29,31-33}$ (Table 3). In four of the 12 studies, the time-point at which mortality was recorded was not reported or was unclear. ${ }^{18,24}$ ${ }^{25,} 29$ Calorie delivery that met an overfeeding inclusion criterium was not found to be associated with increased mortality when compared to lower calorie delivery in the four studies (two randomized; ${ }^{12,17}$

This article is protected by copyright. All rights reserved. 
two non-randomized ${ }^{18,19}$ ) that reported a significant difference in calorie delivery between treatment groups.

In a sensitivity analysis based on the Bayesian approach for the four studies that reported differences in calorie delivery, where only one group met a criterium for overfeeding, there was no demonstrable treatment effect of overfeeding on trial reported mortality: median OR: 0.983 (95\% Crl: $0.517-1.832$ ).

Outcomes related to organ support and respiratory parameters are reported in Table 4. Data relating to mechanical ventilation were reported in seven randomized trials ${ }^{12}, 17,21-23,25,26$ and six nonrandomized studies. ${ }^{18,19,28-30,32}$ Seven studies reported the number of mechanically ventilated

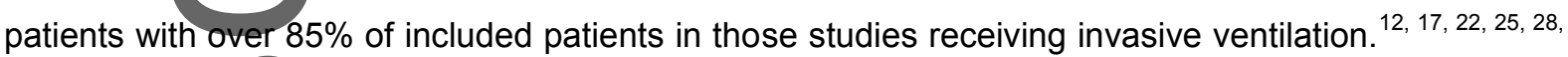
30, 32 There were no between-group differences in rates of ventilation in studies that reported differences in calorie delivery between the two arms. Five randomized trials ${ }^{12,17,21,25,26}$ and four nonrandomized studies $^{18,19,29,30}$ reported either the duration of mechanical ventilation ${ }^{18,19,21,25,26,29,30}$ or the number of ventilator-free days to day $28 .{ }^{12,17}$ The two randomized trials reporting a difference in calorie delivery between groups did not find an association between calorie overfeeding and ventilator-free days. No studies reported the development of new onset respiratory failure. Only one randomized study ${ }^{12}$ reported the percentage of patients receiving vasopressor support and acute renal replacement and the number of organ-free days. Calorie overfeeding was not associated with an increase in the number of patients requiring vasopressors or acute renal replacement therapy or the duration of support.

Five randomized trials ${ }^{12,21,24-26}$ and three non-randomized studies ${ }^{18,19,29}$ reported one or more infectious complications ( $44 \%$ of included studies) (Table 5). Calorie overfeeding was not found to be associated with increased rates of bacteremia or antimicrobial administration in the one randomized trial that reported a significant difference in calorie delivery between treatment groups, ${ }^{12}$ while one non-randomized trial reported an increased duration of antibiotic therapy with overfeeding (27.4 (17.3) vs $16.6(11.7)$ days $).{ }^{18}$

Calorie overfeeding was associated with hyperglycemia and increased insulin administration in one randomized trial reporting a significant difference in calorie delivery between treatment groups. ${ }^{12} \mathrm{~A}$ smaller non-randomized trial also reported a significant increase in total insulin administration with overfeeding in a sub-group of burns patients ${ }^{19}$ (Table 6), while a small randomized trial reported no difference in mean concentrations of glucose and insulin or glucose turnover during the study. ${ }^{27}$ One large randomized trial reported increased gastric residual volumes and promotility administration with overfeeding. ${ }^{12}$ One randomized trial reported a similar frequency of diarrhoea between study arms, both of which were pverfed. ${ }^{20}$ No studies reported new-onset fever or pancreatitis.

This article is protected by copyright. All rights reserved. 


\section{Risk of bias}

The risk of bias for the randomized controlled trials is shown in the supplemental files; Figure S1. According to the Cochrane 'Risk of Bias' tool classifications three studies were considered to have low risk of bias ${ }^{12,17,27}$, six studies had met the criteria of 'some concerns ${ }^{, 20,22-26}$ and one study had a high risk of bias

A funnell plot for publication bias for the outcome of mortality was not constructed as less than 10 randomized papers were available.

\section{DISCUSSION \\ Overview of results}

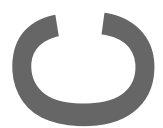

This systematic review evaluating the effects of enteral calorie overfeeding in critically ill adults did not find an association with mortality or key clinical outcomes including duration of mechanical ventilation and infectious complications. However, only 18 studies fulfilled the pre-defined criteria for calorie overfeeding in one or more patient cohorts, of which only half were randomized trials and only four reported a separation in calorie delivery between treatment arms in which only one arm met the predefined criterium for overfeeding. The paucity of high-quality evidence precludes any meaningful conclusions regarding the potential for harm associated with enteral calorie overfeeding. Our findings do not provide evidence to support the stated risks of overfeeding in international guidelines ${ }^{8}$ and opinion pieces. ${ }^{1,35,36}$

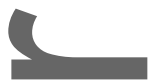

\section{Relationship to other literature}

The major clinical concerns of overfeeding are increased $\mathrm{CO}_{2}$ production, and hence prolonged ventilatory dependence, and glycemic control. The literature suggesting any adverse effects of calorie overfeeding on respiratory outcomes primarily relates to parenterally fed patients. ${ }^{37-39}$ Our review did not find that enteral calorie overfeeding was associated with worse outcomes. Moreover, an observational study of long-term mechanically ventilated patients, in which overfeeding was defined as $>110 \%$ of estimated caloric goals using indirect calorimetry, reported lower minute ventilation with greater calorie delivery. ${ }^{40} \mathrm{~A}$ post-hoc analysis of an international database also reported more ventilator-free days with increased calorie delivery. ${ }^{41}$ While few studies reported glycaemia outcomes our review only found one study, albeit a large randomised trial, demonstrating inferior glycemic control with overfeeding with an increase in the number of patients receiving insulin and the daily insulin dose. However, interpretation of these results should consider macronutrient composition as the group receiving greater calories received a higher carbohydrate dose (180 g vs $125 \mathrm{~g}$ per liter enteral nutrition formulation). ${ }^{12}$ Furthermore, as insulin resistance and stress-induced hyperglycemia are common in critical illness it is likely that blood glucose concentrations are directly related to the

This article is protected by copyright. All rights reserved. 
amount of carbohydrate delivered, even when enteral calorie delivery does not meet the definition of overfeeding.

\section{Strengths/weaknesses}

This systematic review provides the first comprehensive analysis of studies reporting enteral calorie overfeeding (as defined in our review) to critically ill patients and associated clinical outcomes. Strengths of this review include a comprehensive literature search, adherence to a pre-registered protocol, limiting the search to only include studies of enteral calorie delivery, the recommended route for nutrition in the critically ill, ${ }^{8,9}$ and the inclusion of a large, recent, multi-centre, randomized, doubleblind enteral nutrition trial evaluating increased calorie delivery in mechanically ventilated patients. ${ }^{12}$ While several definitions of overfeeding were included in order to capture the breadth of research in this area, these definitions are not standardized. This lack of uniformity may have limited the number of identified publications and under- or over- estimated the effect of overfeeding on clinical outcomes. Further, only four studies that met our definition of calorie overfeeding included only one arm that was overfed. Of these, only two were randomized (and one of these was the pilot trial for the larger randomized study). The third study was non-randomized and patients were only overfed at particular time-points rather than the entire study duration, and the fourth, in a sub-set of burns patients, overfed for the kcal/kg per day criterium only and not total kcal per day. In addition, the mean calorie intake at a group level only was considered, and hence it should be recognised that inter-patient variation means it is likely not all patients within the overfed group were overfed.

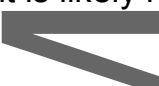

The small number of studies identified, combined with heterogeneity in calculating calorie goals and outcome reporting precluded the synthesis of results. Only four studies used indirect calorimetry, the recommended technique for estimating metabolic rate. ${ }^{8}$ For those studies that used a fixed weight or predictive equation to prescribe calories, the determination of calorie overfeeding will differ according to the use of actual, ideal or adjusted weight to calculate calorie delivery. The lack of a uniform approach as to which weight to use highlights the need to standardize weight, not only for critical care nutrition research but also for calculating calorie requirements at the patient's bedside.

\section{Implications for clinicians:}

This review demonstrates a lack of high-quality evidence supporting the view that enteral calorie delivery to a level that meets our pre-defined criteria of overfeeding in critical illness is harmful, with the exception of ypper gastrointestinal intolerance and poorer glycemic control. Clinicians should however remain cautious about overfeeding via intravenous routes.

Implications for further research:

Prior to implementing changes in practice, further research should assess the effects of calorie overfeeding via the enteral route on physiologically-plausible clinical outcomes such as respiratory outcomes and glycemic control. In particular, differentiation as to the effect of specific macronutrient overfeeding from total calorie overfeeding via the enteral route is required. High protein intake is

This article is protected by copyright. All rights reserved. 
recommended in current nutrition guidelines ${ }^{8,9}$ and yet the safety and benefits of this remain uncertain. In addition, it is recommended that a consensus statement for standardized reporting of demographics, caloric goals, calorie and macronutrient delivery, and outcome measures be developed in order to allow synthesis of trials in the field of critical care nutrition. A systematic review on the quality of reporting of nutrition variables in critical care nutrition trials is currently underway (https://www.crd.york.ac.uk/prospero/; CRD42019127194).

\section{Conclusion:}

The literature on overfeeding of enteral calories is sparse. Limited high quality data of the impact of calorie overfeeding on outcomes exists; however documented adverse effects from calorie overfeeding by the enteral route in critical illness are minor and concerns of overfeeding in enterally fed critically ill patients are not supported by the current literature, other than increased gastrointestinal intolerance and a greater need for insulin to manage blood glucose levels. This evidence should be carefully considered by trialists in the design of future studies aimed to deliver full calorie targets.

\section{Acknowledgements:}

Tess Broadley for assistance with the exclusion of papers from title and abstract and collection of fulltext papers. John Moran for assistance with the statistical analyses.

\section{Statement of Authorship:}

LSC, DJ, EJR, MJC, and SP contributed to the conceptualization and research design. LSC and LW performed the literature review. LSC, LW, EJR, and DJ collected and analyzed the data. All authors provided crucial intellectual input to the analysis and interpretation of the results and drafting of the manuscript All authors read and approved the final manuscript.

\section{Conflict of Interest Statement:}

The authors have no relevant financial or personal disclosures in relation to this work.

Funding:

This research did not receive any specific grant from funding agencies in the public, commercial, or not-for-profit sectors.

This article is protected by copyright. All rights reserved. 


\section{References:}

1. Klein CJ, Stanek GS, Wiles CE, 3rd. Overfeeding macronutrients to critically ill adults: metabolic complications. Journal of the American Dietetic Association. Jul 1998;98(7):795806

2. Griffiths RD. Too much of a good thing: the curse of overfeeding. Critical Care (London, England). 2007;11(6):176.

3. Chapman M, Fraser R, Vozzo R, et al. Antro-pyloro-duodenal motor responses to gastric and duodenatnutrient in critically ill patients. Gut. Oct 2005;54(10):1384-1390.

4. Lin HC, Doty JE, Reedy TJ, Meyer JH. Inhibition of gastric emptying by glucose depends on length of intestine exposed to nutrient. American Journal of Physiology. Feb 1989;256(2 Pt 1): $404-411$.

5. Chapman MJ, Nguyen NQ, Deane AM. Gastrointestinal dysmotility: clinical consequences and management of the critically ill patient. Gastroenterology Clinics of North America. Dec 2011;40(4):725-739.

6. Ali Abdelhamid Y, Cousins CE, Sim JA, et al. Effect of Critical Illness on Triglyceride Absorption. JPEN Journal of Parenteral \& Enteral Nutrition. 2015;39(8):966-972.

7. Chapman MJ, Fraser RJ, Matthews G, et al. Glucose absorption and gastric emptying in critical illness. Critical Care (London, England). 2009;13(4):R140.

8. Singer P, Blaser AR, Berger MM, et al. ESPEN guideline on clinical nutrition in the intensive care unit. Clinical Nutrition. Feb 2019;38(1):48-79.

9. McClave SA, Taylor BE, Martindale RG, et al. Guidelines for the Provision and Assessment of Nutrition Support Therapy in the Adult Critically III Patient: Society of Critical Care Medicine (SCCM) and American Society for Parenteral and Enteral Nutrition (A.S.P.E.N.). JPEN Journal of Parenteral \& Enteral Nutrition. 2016;40(2):159-211.

10. Moher D, Liberati A, Tetzlaff J, Altman DG. Preferred reporting items for systematic reviews and meta-analyses: the PRISMA statement. PLoS Med. Jul 21 2009;6(7):e1000097.

11. Ridley EJ, Davies AR, Hodgson CL, Deane A, Bailey M, Cooper DJ. Delivery of full predicted energy from nutrition and the effect on mortality in critically ill adults: A systematic review and meta-analysis of randomised controlled trials. Clinical Nutrition. 2018;37(6):1913-1925.

12. Target Investigators, for the ANZICS Clinical Trials Group. Energy-Dense versus Routine Enteral Nutrition in the Critically III. The New England Journal of Medicine. 2018;379(19):1823-1834.

13. Wan X, Wang W, Liu J, Tong T. Estimating the sample mean and standard deviation from the sample size, median, range and/or interquartile range. BMC Med Res Methodol. Dec 19 2014; 14:135.

14. Rover C, Wandel S, Friede T. Model averaging for robust extrapolation in evidence synthesis. Stat Med. Feb 20 2019;38(4):674-694.

15. Review Manager (RevMan) [Computer program]. Version 5.3. Copenhagen: The Nordic Cochrane Centre, The Cochrane Collaboration, 2014.

This article is protected by copyright. All rights reserved. 
16. Higgins JPT, Green S (editors). Cochrane handbook for systematic reviews of interventions; Version 5.1.0 [updated March 2011]. The Cochrane Collaboration, 2011. Available from www.handbook.cochrane.org.

17. Peake SL, Davies AR, Deane AM, et al. Use of a concentrated enteral nutrition solution to increase calorie delivery to critically ill patients: a randomized, double-blind, clinical trial. American Journal of Clinical Nutrition. 2014;100(2):616-625.

18. Dickerson RN, Boschert KJ, Kudsk KA, Brown RO. Hypocaloric enteral tube feeding in critically ill obese patients. [Erratum appears in Nutrition. 2003 Jul-Aug;19(7-8):700]. Nutrition. Mar 2002;18(3):241-246.

19. Soguel L, Chiolero RL, Ruffieux C, Berger MM. Monitoring the clinical introduction of a glutamine and antioxidant solution in critically ill trauma and burn patients. Nutrition. Nov-Dec 2008;24(11-12):1123-1132.

20. Diboune $M$, Ferard $G$, Ingenbleek $Y$, et al. Composition of phospholipid fatty acids in red blood cell membranes of patients in intensive care units: effects of different intakes of soybean oil, medium-chain triglycerides, and black-currant seed oil. JPEN J Parenter Enteral Nutr. Mar-Apr 1992;16(2):136-141.

21. Moore FA, Moore EE, Kudsk KA, et al. Clinical benefits of an immune-enhancing diet for early postinjury enteral feeding. Journal of Trauma-Injury Infection \& Critical Care. Oct 1994;37(4):607-615.

22. van den Berg B, Bogaard JM, Hop WC. High fat, low carbohydrate, enteral feeding in patients weaning from the ventilator. Intensive Care Med. Aug 1994;20(7):470-475.

23. Long CL, Nelson KM, DiRienzo DB, et al. Glutamine supplementation of enteral nutrition: impact on whole body protein kinetics and glucose metabolism in critically ill patients. JPEN J Parenter Enteral Nutr. Nov-Dec 1995;19(6):470-476.

24. Mendez C, Jurkovich GJ, Garcia I, Davis D, Parker A, Maier RV. Effects of an immuneenhancing diet in critically injured patients. Journal of Trauma-Injury Infection \& Critical Care. May 1997;42(5):933-940; discussion 940-931.

25. Garret D. Patenaude J, Nedelec B, et al. Decreased mortality and infectious morbidity in adult burn patients given enteral glutamine supplements: a prospective controlled, randomized clinical trial. Critical Care Medicine. 2003;31(10):2444-2449.

26. Falcao de Arruda IS, de Aguilar-Nascimento JE. Benefits of early enteral nutrition with glutamine and probiotics in brain injury patients. Clinical Science. Mar 2004;106(3):287-292.

27. Berger MM, Binnert C, Chiolero RL, et al. Trace element supplementation after major burns increases burned skin trace element concentrations and modulates local protein metabolism but not whole-body substrate metabolism. American Journal of Clinical Nutrition. 2007;85(5):1301-1306.

28. Cerra FB, Shronts EP, Raup S, Konstantinides N. Enteral nutrition in hypermetabolic surgical patients. Crit Care Med. Jul 1989;17(7):619-622.

29. Farber MS, Moses J, Korn M. Reducing costs and patient morbidity in the enterally fed intensive care unit patient. JPEN J Parenter Enteral Nutr. Jan-Feb 2005;29(1 Suppl):S62-69.

This article is protected by copyright. All rights reserved. 
30. van den Berg B, Stam $\mathrm{H}$. Metabolic and respiratory effects of enteral nutrition in patients during mechanical ventilation. Intensive Care Med. 1988;14(3):206-211.

31. Buonpane-EA, Brown RO, Boucher BA, Fabian TC, Luther RW. Use of fibronectin and somatomedin- $C$ as nutritional markers in the enteral nutrition support of traumatized patients. Crit Care Med. Feb 1989;17(2):126-132.

32. Ravasco P, Camilo ME. Tube feeding in mechanically ventilated critically ill patients: a prospective clinical audit. Nutrition in Clinical Practice. 2003;18(5):427-433.

33. Shields BA, Pidcoke HF, Chung KK, et al. Are visceral proteins valid markers for nutritional status in the burn intensive care unit? Journal of Burn Care \& Research. 2015;36(3):375-380.

34. World Health Organization. Body mass index; 2019.

35. Reid C. Frequency of under- and overfeeding in mechanically ventilated ICU patients: causes and possible consequences. Journal of Human Nutrition \& Dietetics. Feb 2006;19(1):13-22.

36. Fraipont $\nabla$, Preiser JC. Energy estimation and measurement in critically ill patients. Jpen: Journal of Parenteral \& Enteral Nutrition. Nov 2013;37(6):705-713.

37. Askanazi S, Carpentier YA, Elwyn DH, et al. Influence of total parenteral nutrition on fuel utilization in injury and sepsis. Annals of Surgery. Jan 1980;191(1):40-46.

38. Askanazi J, Rosenbaum SH, Hyman Al, Silverberg PA, Milic-Emili J, Kinney JM. Respiratory changes induced by the large glucose loads of total parenteral nutrition. JAMA. Apr 11 1980;243(14):1444-1447.

39. Liposky JM, Nelson LD. Ventilatory response to high caloric loads in critically ill patients. Critical Care Medicine. May 1994;22(5):796-802.

40. McClave SA, Lowen CC, Kleber MJ, et al. Are patients fed appropriately according to their caloric requirements? Jpen: Journal of Parenteral \& Enteral Nutrition. Nov-Dec 1998;22(6):375-381.

41. Elke G, Wang M, Weiler N, Day AG, Heyland DK. Close to recommended caloric and protein intake by enteral nutrition is associated with better clinical outcome of critically ill septic patients: secondary analysis of a large international nutrition database. Critical Care (London, England).Feb 10 2014;18(1):R29.

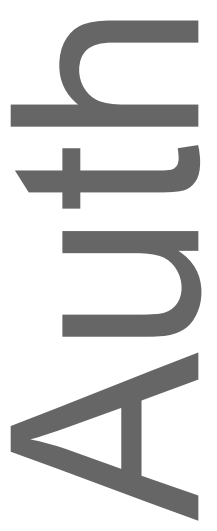

This article is protected by copyright. All rights reserved. 
Table 1. Study and patient characteristics

\begin{tabular}{|c|c|c|c|c|c|c|c|c|c|c|c|c|c|c|c|}
\hline \multirow[t]{2}{*}{$\begin{array}{l}\text { Author, } \\
\text { Year }\end{array}$} & \multirow{2}{*}{$\begin{array}{c}\text { Study } \\
\text { desig } \\
\text { n }\end{array}$} & \multirow[t]{2}{*}{$\begin{array}{l}\mathbf{N}^{\circ} . \\
\text { ar }\end{array}$} & \multirow[t]{2}{*}{$\begin{array}{c}\text { Interve } \\
\text { ntion }\end{array}$} & \multirow[t]{2}{*}{$\begin{array}{c}\text { Populatio } \\
n\end{array}$} & \multirow[t]{2}{*}{$\mathbf{N}$} & \multicolumn{2}{|c|}{ Age, years } & \multicolumn{2}{|c|}{$\begin{array}{c}\text { Sex Male, } \mathrm{n} \\
\text { (\%) }\end{array}$} & \multicolumn{2}{|c|}{ Weight, $\mathrm{kg}^{\mathrm{a}}$} & \multicolumn{2}{|c|}{$\mathrm{BMI}, \mathrm{kg} / \mathrm{m}^{2}$} & \multicolumn{2}{|c|}{ Severity illness } \\
\hline & & & & & & $\begin{array}{l}\text { Grou } \\
\text { p } 1\end{array}$ & $\begin{array}{c}\text { Group } \\
2\end{array}$ & $\begin{array}{c}\text { Grou } \\
\text { p } 1\end{array}$ & $\begin{array}{c}\text { Grou } \\
\text { p } 2\end{array}$ & $\begin{array}{c}\text { Grou } \\
\text { p } 1\end{array}$ & $\begin{array}{c}\text { Group } \\
2\end{array}$ & $\begin{array}{c}\text { Grou } \\
\text { p } 1\end{array}$ & $\begin{array}{c}\text { Group } \\
2\end{array}$ & $\begin{array}{c}\text { Grou } \\
\text { p } 1\end{array}$ & $\begin{array}{c}\text { Grou } \\
\text { p } 2\end{array}$ \\
\hline \multicolumn{16}{|c|}{ Randomized trials } \\
\hline $\begin{array}{l}\text { Diboun } \\
\mathrm{e} \\
1992^{20}\end{array}$ & $\begin{array}{r}\text { RCT } \\
\\
\\
\end{array}$ & & $\begin{array}{l}\text { EN } \\
\text { with } 3 \\
\text { differe } \\
\text { ntFA } \\
\text { compo } \\
\text { sition }\end{array}$ & $\begin{array}{l}\text { Head- } \\
\text { injury, } \\
\text { cerebral } \\
\text { stroke }\end{array}$ & 32 & $\begin{array}{l}57.7 \\
(26.2)\end{array}$ & $\begin{array}{l}49.1 \\
(24.9)\end{array}$ & $6(55)$ & $\begin{array}{l}6 \\
(55)\end{array}$ & $\begin{array}{l}60.7 \\
(14.9)\end{array}$ & $\begin{array}{l}60.0 \\
(10.2)\end{array}$ & NR & NR & NR & NR \\
\hline $\begin{array}{l}\text { Van } \\
\text { den } \\
\text { Berg } \\
1994^{22}\end{array}$ & RCT & & & $\begin{array}{l}\text { COPD, } \\
\text { trauma, } \\
\text { neurologi } \\
\text { cal illness, } \\
\text { pneumon } \\
\text { ia }\end{array}$ & 32 & NR & NR & $\begin{array}{l}13 \\
(76)\end{array}$ & $\begin{array}{l}10 \\
(67)\end{array}$ & $\begin{array}{l}1.15 \\
(0.27) \\
\% \\
\text { IBW }\end{array}$ & $\begin{array}{l}0.94 \\
(0.24) \\
\% \\
\text { IBW }\end{array}$ & NR & NR & $\begin{array}{l}\text { AP II: } \\
14 \text { (4) }\end{array}$ & $\begin{array}{l}\text { AP II: } \\
15 \text { (4) }\end{array}$ \\
\hline $\begin{array}{l}\text { Moore } \\
1994^{21}\end{array}$ & RCT & & $\begin{array}{l}d \\
\text { 'stress' } \\
\text { EN }\end{array}$ & $\begin{array}{l}\text { Major } \\
\text { torso } \\
\text { trauma }\end{array}$ & 98 & $\begin{array}{l}30.1 \\
(1.3)^{c}\end{array}$ & $\begin{array}{l}30.7 \\
(1.5)^{c}\end{array}$ & $\begin{array}{l}36 \\
(71)\end{array}$ & $\begin{array}{l}33 \\
(70)\end{array}$ & $\begin{array}{l}76.5 \\
(2.0)^{c} \\
\text { IBW } \\
\text { for } \\
\text { non- } \\
\text { obese } \\
\text { ' } \\
\text { mode } \\
\text { rate } \\
\text { obesit } \\
\text { y adj }\end{array}$ & $\begin{array}{l}77.9 \\
(2.7)^{\mathrm{C}} \\
\text { IBW } \\
\text { for } \\
\text { non- } \\
\text { obese } \\
\text { ' } \\
\text { mode } \\
\text { rate } \\
\text { obesit } \\
\text { y adj }\end{array}$ & NR & NR & $\begin{array}{l}\text { ISS: } \\
20.6 \\
(1.2)^{c} \\
\text { GCS: } \\
13.7 \\
(0.3)^{c}\end{array}$ & $\begin{array}{l}\text { ISS: } \\
21.8 \\
(1.2)^{\mathrm{c}} \\
\text { GCS: } \\
13.7 \\
(0.4)^{\mathrm{c}}\end{array}$ \\
\hline $\begin{array}{l}\text { Long } \\
1995^{23}\end{array}$ & RCT & & & Trauma & 30 & $\begin{array}{l}35.1 \\
(3.2)^{c}\end{array}$ & $\begin{array}{l}29.4 \\
(3.5)^{c}\end{array}$ & $6(43)$ & $\begin{array}{l}10 \\
(63)\end{array}$ & $\begin{array}{l}72.9 \\
(3.6)^{c}\end{array}$ & $\begin{array}{l}73.8 \\
(3.8)^{c}\end{array}$ & NR & NR & $\begin{array}{l}\text { ISS: } \\
33.8 \\
(2.1)^{\mathrm{c}}\end{array}$ & $\begin{array}{l}\text { ISS: } \\
30.0 \\
(1.5)^{c}\end{array}$ \\
\hline $\begin{array}{l}\text { Mendez } \\
1997^{24}\end{array}$ & RCT & & $\begin{array}{l}\text { Immun } \\
\text { e- } \\
\text { enhanc } \\
\text { ing vs } \\
\text { standar } \\
\text { d EN }\end{array}$ & $\begin{array}{l}\text { Obese } \\
\text { trauma }\end{array}$ & 43 & $\begin{array}{l}25.5 \\
(1.2)^{c}\end{array}$ & $\begin{array}{l}35.3 \\
(2.7)^{c}\end{array}$ & $\begin{array}{l}14 \\
(64)\end{array}$ & $\begin{array}{l}15 \\
(71)\end{array}$ & NR & NR & NR & NR & $\begin{array}{l}\text { AP: } \\
15.05 \\
(1.38) \\
{ }^{c} \\
\text { ISS: } \\
28.2 \\
(2.1)^{c}\end{array}$ & $\begin{array}{l}\text { AP: } \\
15.67 \\
(1.05) \\
{ }^{c} \\
\text { ISS: } \\
32.2 \\
(2.3)^{c}\end{array}$ \\
\hline $\begin{array}{l}\text { Garrel } \\
2003^{25}\end{array}$ & RCT & & & $\begin{array}{l}\text { Severe } \\
\text { burns } \\
(\geq 20 \% \\
\text { TBSA) }\end{array}$ & 41 & $38(8)$ & $39(7)$ & $\begin{array}{l}21 \\
(95)\end{array}$ & $\begin{array}{l}16 \\
(84)\end{array}$ & $\begin{array}{l}92 \\
(13)\end{array}$ & $\begin{array}{l}86 \\
(29)\end{array}$ & NR & NR & NR & NR \\
\hline $\begin{array}{l}\text { Falcao } \\
\text { de } \\
\text { Arruda } \\
2004^{26}\end{array}$ & RCT & & $\begin{array}{l}\text { Glutam } \\
\text { ine/ } \\
\text { probiot } \\
\text { ic- } \\
\text { enriche }\end{array}$ & TBI & 20 & $\begin{array}{l}30 \\
(9.7)^{d}\end{array}$ & $\begin{array}{l}30 \\
(8.7)^{d}\end{array}$ & $9(90)$ & $\begin{array}{l}10 \\
(100)\end{array}$ & $\begin{array}{l}\text { NR, } \\
\text { mean } \\
\text { IBW }\end{array}$ & $\begin{array}{l}\text { NR, } \\
\text { mean } \\
\text { IBW }\end{array}$ & $\begin{array}{l}22.5 \\
(1.0)^{d}\end{array}$ & $\begin{array}{l}22.5 \\
(1.0)^{d}\end{array}$ & $\begin{array}{l}\text { GCS: } \\
7 \\
(1.3)^{d} \\
\text { TISS: } \\
32(5)\end{array}$ & $\begin{array}{l}\text { GCS: } \\
7.5 \\
(1.3)^{d} \\
\text { TISS: } \\
34(8)\end{array}$ \\
\hline $\begin{array}{l}\text { Berger } \\
2007^{27}\end{array}$ & RCT & 2 & & Burns & 21 & $\begin{array}{l}38 \\
(16)\end{array}$ & $\begin{array}{l}46 \\
(15)\end{array}$ & $6(60)$ & $\begin{array}{l}9 \\
(82)\end{array}$ & NR & NR & NR & NR & NR & NR \\
\hline $\begin{array}{l}\text { Peake } \\
2014^{17}\end{array}$ & $\begin{array}{l}\text { RCT } \\
\text { pilot }\end{array}$ & 2 & $\begin{array}{l}\text { I vs } 1.5 \\
\mathrm{kcal} / \mathrm{ml} \\
\mathrm{EN}\end{array}$ & $\begin{array}{l}\text { General } \\
\text { ICU, MV }\end{array}$ & 112 & $\begin{array}{l}56.4 \\
(16.8)\end{array}$ & $\begin{array}{l}56.5 \\
(16.1)\end{array}$ & $\begin{array}{l}42 \\
(74)\end{array}$ & $\begin{array}{l}41 \\
(75)\end{array}$ & $\begin{array}{l}83 \\
(23.2) \\
A B W \\
67 \\
(9.2) \\
\text { IBW }\end{array}$ & $\begin{array}{l}77 \\
(16.4) \\
A B W \\
67 \\
(9.1) \\
\text { IBW }\end{array}$ & $\begin{array}{l}27.8 \\
(7.9)\end{array}$ & $\begin{array}{l}26.2 \\
(6.4)\end{array}$ & $\begin{array}{l}\text { AP II: } \\
23 \\
(9.1)\end{array}$ & $\begin{array}{l}\text { AP II: } \\
22 \\
(8.9)\end{array}$ \\
\hline TARGET & RCT & 2 & 1 vs 1.5 & General & 395 & 57.2 & 57.5 & 1221 & 1272 & 84.6 & 84.9 & 29.2 & 29.3 & AP II: & AP II: \\
\hline
\end{tabular}

This article is protected by copyright. All rights reserved. 


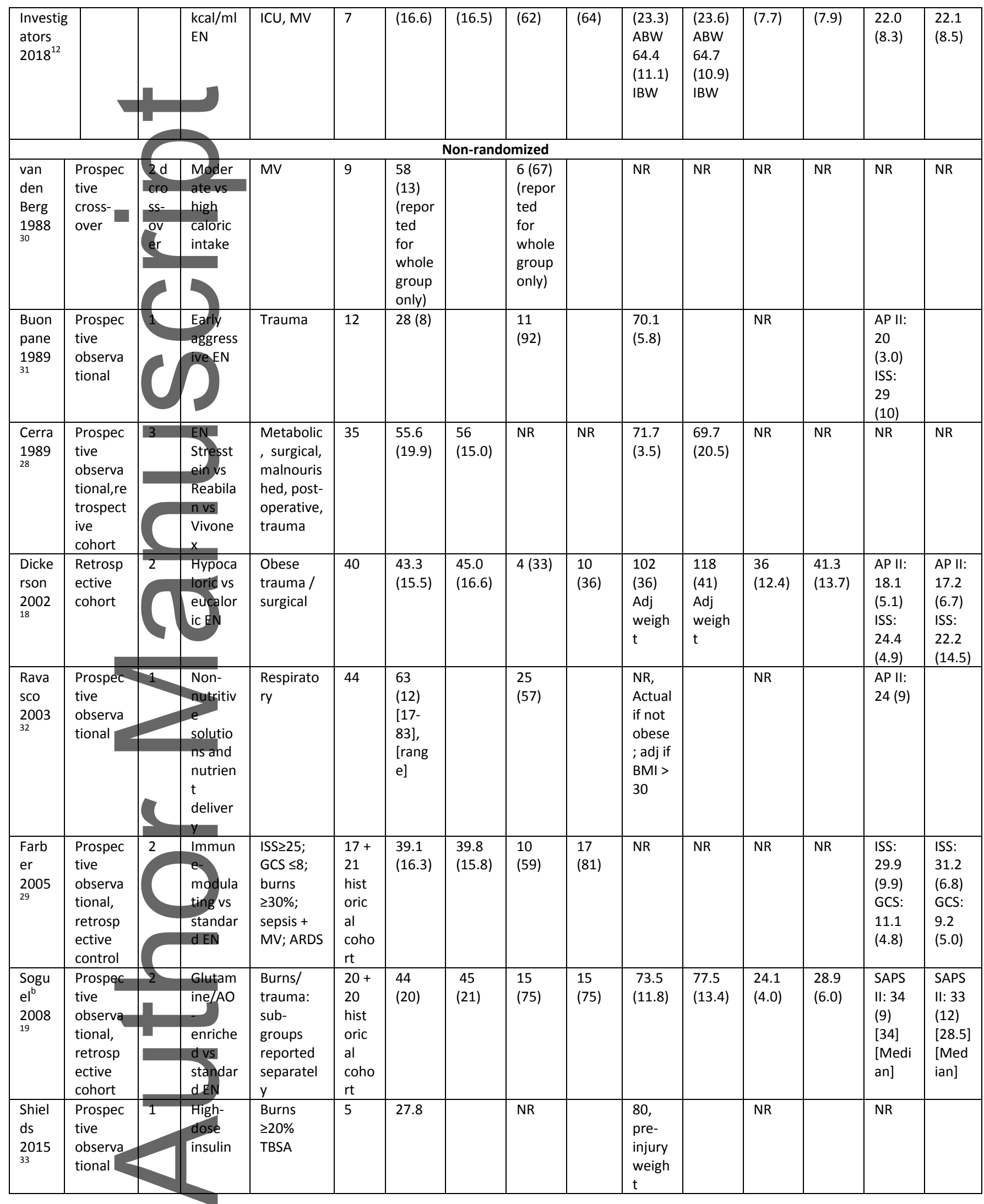

AO, antioxidants; APACHE, Acute Physiology and Chronic Health Evaluation; ARDS, acute respiratory distress syndrome; BSA, body surface area; COPD, chronic obstructive pulmonary disease; EN, enteral nutrition; EPA, eicosapentaenoic acid (omega 6); FA, fatty acids; Fn, fibronectin; GLA, gamma linolenic acid (omega 3); ICU, Intensive Care Unit; ISS, Injury Severity Score; IV, intravenous; MV, mechanical ventilation; RCT, Randomized controlled trial; Sm-C, somatomedin-C; Yrs, years; TBI, traumatic brain injury; TBSA, total body surface area; TE, trace elements; TISS, Trauma Injury severity score. Data are reported as mean (standard deviation) unless otherwise stated. Group 1 received the highest calorie delivery.

This article is protected by copyright. All rights reserved. 
${ }^{\text {a }}$ Weight assumed to be actual weight unless indicated

${ }^{b}$ Patient population included both burns and trauma patients. Data presented on burns subgroup only.

${ }^{\mathrm{c}}$ Standard error of the mean

${ }^{d}$ Median (range) converted to mean (SD)

Cerra $1989^{28}$ also included a third arm for which the mean age was $54.6(10.7)$ years.

Diboune $1992^{20}$ also included a third arm for which the M,F was 4,6, mean age was 51.7 (15.1) years, and mean time-point of study

conduct was $26.3(18.1)$ days.

Table 2. Caloric prescription and delivery

\begin{tabular}{|c|c|c|c|c|c|c|c|c|c|}
\hline \multirow[t]{2}{*}{ Author } & \multirow{2}{*}{$\begin{array}{l}\text { Calorie } \\
\text { orescription } \\
\text { methods }\end{array}$} & \multicolumn{3}{|c|}{ Calorie delivery, kcal/d } & \multirow[t]{2}{*}{$\begin{array}{c}\text { Definition of } \\
\text { overfeeding } \\
\text { met }\end{array}$} & \multicolumn{2}{|c|}{$\begin{array}{c}\text { Time from ICU } \\
\text { admission to start } \\
\text { study, days }\end{array}$} & \multicolumn{2}{|c|}{$\begin{array}{c}\text { Duration } \\
\text { intervention, } \\
\text { days }\end{array}$} \\
\hline & & Group 1 & Group 2 & $\begin{array}{c}\text { p-value } \\
\text { for calorie } \\
\text { delivery }\end{array}$ & & Group 1 & Group 2 & $\begin{array}{c}\text { Group } \\
1\end{array}$ & $\begin{array}{c}\text { Group } \\
2\end{array}$ \\
\hline \multicolumn{10}{|c|}{ Randomized trials } \\
\hline $\begin{array}{l}\text { Diboune } \\
1992^{20}\end{array}$ & & 2950 & 2950 & NR & $>2000 \mathrm{kcal}$ & $\begin{array}{l}27.9 \\
(37)\end{array}$ & $\begin{array}{l}26.5 \\
(32.4)\end{array}$ & NR & NR \\
\hline $\begin{array}{l}\text { Van den Berg } \\
1994^{22}\end{array}$ & $\begin{array}{l}\text { Scholfield } 1.5 x \\
\text { BMR }\end{array}$ & $2003(277)$ & $1943(306)$ & NR & $>2000 \mathrm{kcal}$ & NR & NR & 6 & 4 \\
\hline Moore $1994^{21}$ & 35 kcal/ & $\begin{array}{l}\mathrm{d} 326.4 \\
(1.4) \\
\mathrm{kcal} / \mathrm{kg} / \mathrm{d}^{\mathrm{a}} \\
\mathrm{d} 729.2 \\
(3.0) \\
\mathrm{kcal} / \mathrm{kg} / \mathrm{d}^{\mathrm{a}}\end{array}$ & $\begin{array}{l}\mathrm{d} 324.1 \\
(1.8) \\
\mathrm{kcal} / \mathrm{kg} / \mathrm{d}^{\mathrm{a}} \\
\mathrm{d} 726.8 \\
(2.3) \\
\mathrm{kcal} / \mathrm{kg} / \mathrm{d}^{\mathrm{a}}\end{array}$ & NR & $>25 \mathrm{kcal} / \mathrm{kg} / \mathrm{d}$ & NR & NR & $7(0.5)$ & $\begin{array}{l}8.2 \\
(0.4)\end{array}$ \\
\hline Long $1995^{23}$ & $30 \mathrm{kcal} / \mathrm{k}$ & $\begin{array}{l}28.6(1.2) \\
\mathrm{kcal} / \mathrm{kg} / \mathrm{d}\end{array}$ & $\begin{array}{l}25.3(1.2) \\
\mathrm{kcal} / \mathrm{kg} / \mathrm{d}\end{array}$ & p 0.07 & $>25 \mathrm{kcal} / \mathrm{kg} / \mathrm{d}$ & $28.9 \mathrm{hrs}$ & $27.7 \mathrm{hrs}$ & NR & NR \\
\hline $\begin{array}{l}\text { Mendez } \\
1997^{24}\end{array}$ & & $\begin{array}{l}2200(200) \\
29.5(2.6) \\
\mathrm{kcal} / \mathrm{kg} / \mathrm{d}\end{array}$ & $\begin{array}{l}2000(185) \\
26.3(3.2) \\
\mathrm{kcal} / \mathrm{kg} / \mathrm{d}\end{array}$ & NR & $\begin{array}{l}>2000 \mathrm{kcal} \\
>25 \mathrm{kcal} / \mathrm{kg} / \mathrm{d}\end{array}$ & $2.5(0.2)$ & $2.6(0.3)$ & $\begin{array}{l}9.1 \\
(0.6)\end{array}$ & $\begin{array}{l}9.8 \\
(0.6)\end{array}$ \\
\hline Garrel $2003^{25}$ & IC and Curreri & $\begin{array}{l}2937 \\
(1262)\end{array}$ & $\begin{array}{l}2753 \\
(1159)\end{array}$ & NR & $>2000 \mathrm{kcal}$ & NR & NR & NR & NR \\
\hline $\begin{array}{l}\text { Falcao de } \\
\text { Arruda } 2004^{26}\end{array}$ & Weight-based & $2400(232)$ & $2390(206)$ & $p=0.96$ & $>2000 \mathrm{kcal}$ & NR & NR & $13(5)$ & $9(4)$ \\
\hline Berger $2007^{27}$ & $\begin{array}{l}30 \mathrm{kcal} / \mathrm{kg} / \mathrm{d} \text { to } \\
\mathrm{d} 3 \text { then IC: } 105- \\
110 \% \text { REE }\end{array}$ & $\begin{array}{l}2600 \text { by } \\
\text { day } 5 \\
2754 \text { by } \\
\text { day } 10 \\
2900 \text { by } \\
\text { day } 20\end{array}$ & $\begin{array}{l}2600 \text { by } \\
\text { day } 5 \\
2754 \text { by } \\
\text { day } 10 \\
2900 \text { by } \\
\text { day } 20\end{array}$ & NR & $>2000 \mathrm{kcal}$ & NR & NR & NR & NR \\
\hline Peake $2014^{17}$ & $\begin{array}{l}1 \mathrm{ml} / \mathrm{kg} \text { IBW } \\
\text { from height } / \mathrm{hr}\end{array}$ & $\begin{array}{l}27.3(7.4) \\
\mathrm{kcal} / \mathrm{kg} / \mathrm{d}\end{array}$ & $\begin{array}{l}19(6), \\
\mathrm{kcal} / \mathrm{kg} / \mathrm{d}\end{array}$ & $p<0.001$ & $>25 \mathrm{kcal} / \mathrm{kg} / \mathrm{d}$ & $\begin{array}{l}23.3 \\
(17.5) \\
\mathrm{hrs}^{\mathrm{c}} \\
\end{array}$ & $\begin{array}{l}25.0 \\
(21.3) \\
\mathrm{hrs}^{\mathrm{c}} \\
\end{array}$ & $\begin{array}{l}6.7 \\
(3.8)^{c}\end{array}$ & $\begin{array}{l}5.3 \\
(4.6)^{c}\end{array}$ \\
\hline $\begin{array}{l}\text { TARGET } \\
\text { Investigators } \\
2018^{12}\end{array}$ & $\begin{array}{l}1 \mathrm{ml} / \mathrm{kg} \text { IBW } \\
\text { from height } / \mathrm{hr}\end{array}$ & $\begin{array}{l}1863(478) \\
29.1(6.2) \\
\mathrm{kcal} / \mathrm{kg} \\
\mathrm{IBW} / \mathrm{d}\end{array}$ & $\begin{array}{l}1262(313) \\
19.6(4.0) \\
\mathrm{kcal} / \mathrm{kg} \\
\mathrm{IBW} / \mathrm{d}\end{array}$ & $\begin{array}{l}95 \% \mathrm{Cl} \\
576-626 \\
\text { kcal }\end{array}$ & $>25 \mathrm{kcal} / \mathrm{kg} / \mathrm{d}$ & $\begin{array}{l}16.6 \\
(13.8) \\
\mathrm{hrs}^{\mathrm{c}}\end{array}$ & $\begin{array}{l}17.4 \\
(15.1) \\
\mathrm{hrs}^{\mathrm{c}}\end{array}$ & $\begin{array}{l}6.7 \\
(5.9)^{c}\end{array}$ & $\begin{array}{l}6.7 \\
(5.9)^{c}\end{array}$ \\
\hline \multicolumn{10}{|c|}{ Non-randomized trials } \\
\hline $\begin{array}{l}\text { van den Berg } \\
1988^{30}\end{array}$ & $\begin{array}{l}\text { IC: } 1.5 \text { or } 2.0 x \\
\text { REE }\end{array}$ & $3710(600)$ & $2555(553)$ & $\mathrm{NR}$ & $>2000 \mathrm{kcal}$ & NR & NR & NR & NR \\
\hline $\begin{array}{l}\text { Buonpane } \\
1989^{31}\end{array}$ & $\begin{array}{l}\text { Harris Benedict } \\
\text { x SF } 1.5\end{array}$ & $\begin{array}{l}33.2(3.9) \\
\mathrm{kcal} / \mathrm{kg} / \mathrm{d}\end{array}$ & - & $\mathrm{N} / \mathrm{A}$ & $>25 \mathrm{kcal} / \mathrm{kg} / \mathrm{d}$ & $5.3(3.8)$ & - & $\begin{array}{l}19.0 \\
(7.0)\end{array}$ & - \\
\hline Cerra $1989^{28}$ & $30-35 \mathrm{kcal} / \mathrm{kg} / \mathrm{d}$ & $\begin{array}{l}33(6) \\
\mathrm{kcal} / \mathrm{kg} / \mathrm{d}\end{array}$ & $\begin{array}{l}29(4) \\
\mathrm{kcal} / \mathrm{kg} / \mathrm{d}\end{array}$ & NR & $>25 \mathrm{kcal} / \mathrm{kg} / \mathrm{d}$ & NR & NR & $8(1)$ & $8(1)$ \\
\hline $\begin{array}{l}\text { Dickerson } \\
2002^{18}\end{array}$ & Weight-based $^{b}$ & $\begin{array}{l}\text { Wk 1: } 18.5 \\
(4.4) \\
\text { Wk 2: } 25.6 \\
(5.9) \\
\text { Wk 3: } 25.9 \\
(5.5) \\
\text { Wk 4: } 24.7 \\
(6.5)\end{array}$ & $\begin{array}{l}\text { Wk 1: } 13.4 \\
(4.1) \\
\text { Wk 2: } 15.7 \\
(5.1) \\
\text { Wk 3: } 18.6 \\
\text { (3.2) } \\
\text { Wk 4: } 19.2 \\
(4.6)\end{array}$ & $p \leq 0.05$ & $>25 \mathrm{kcal} / \mathrm{kg} / \mathrm{d}$ & $3.8(1.5)$ & $3.3(1.4)$ & $\begin{array}{l}26.3 \\
(14.8)\end{array}$ & $\begin{array}{l}15.4 \\
(10.8)\end{array}$ \\
\hline $\begin{array}{l}\text { Ravasco } \\
2003^{32} \\
\end{array}$ & Harris Benedict & $2034(432)$ & - & $\mathrm{N} / \mathrm{A}$ & $>2000 \mathrm{kcal}$ & NR & - & NR & - \\
\hline Farber $2005^{29}$ & $25-35 \mathrm{kcal} / \mathrm{kg} / \mathrm{d}$ & $2700(562)$ & $2583(441)$ & $p=0.48$ & $>2000 \mathrm{kcal}$ & $3.0(1.3)$ & $3.6(2.2)$ & $18(11)$ & $31(22)$ \\
\hline Soguel $^{d} 2008^{19}$ & Weight-based $^{\mathrm{b}}$ & $1840(840)$ & $1675(945)$ & $p=0.012$ & $>25 \mathrm{kcal} / \mathrm{kg} / \mathrm{d}$ & NR & NR & NR & NR \\
\hline
\end{tabular}

This article is protected by copyright. All rights reserved. 


\begin{tabular}{|l|l|l|l|l|l|l|l|l|l|}
\hline & & $\begin{array}{l}26(12) \\
\mathrm{kcal} / \mathrm{kg} / \mathrm{d}\end{array}$ & $\begin{array}{l}23(13), \\
\mathrm{kcal} / \mathrm{kg} / \mathrm{d}\end{array}$ & & & & & \\
\hline Shields $2015^{33}$ & $\begin{array}{l}\text { Carlson, Milner } \\
\text { and IC }\end{array}$ & $\begin{array}{l}3044 \\
(1613)\end{array}$ & - & N/A & $>2000 \mathrm{kcal}$ & NR & - & NR & - \\
& $\begin{array}{l}39(20) \\
\mathrm{kcal} / \mathrm{kg} / \mathrm{d}\end{array}$ & & & & & \\
\end{tabular}

ABW, Actual body weight; BMI, body mass index; BMR, Basal metabolic rate; d, day; IBW, Ideal body weight; IC, indirect calorimetry; REE, resting energy expenditure; NR, not stated. Data are reported as mean (SD) unless otherwise stated. Group 1 received the highest calorie delivery.

${ }^{a}$ Mean (standard error of the mean)

${ }^{\mathrm{b}}$ Details of formula used not reported

${ }^{c}$ Median (interquartile range)

${ }^{d}$ Patient population included both burns and trauma patients. Data presented on burns subgroup only.

Cerra $1989^{28}$ also included a third arm for which the mean weight was $84(10.6) \mathrm{kg}$, mean calorie delivery was $28(7) \mathrm{kcal} / \mathrm{kg} / \mathrm{d}$ and duration of study intervention was 8 (1) days.

Dibourne, $1992^{20}$ also included a third arm for which the mean weight was $66.4(10.2) \mathrm{kg}$.

Table 3. Mortality

\begin{tabular}{|c|c|c|c|c|c|c|c|c|c|c|}
\hline \multirow[t]{2}{*}{ Author, year } & \multicolumn{2}{|c|}{$\begin{array}{c}\text { CU mortality; } \mathbf{n} \\
(\%)\end{array}$} & \multicolumn{2}{|c|}{$\begin{array}{c}\text { Hospital mortality, } \\
\text { n (\%) }\end{array}$} & \multicolumn{2}{|c|}{$\begin{array}{c}28 \text { day mortality, } \mathbf{n} \\
(\%)\end{array}$} & \multicolumn{2}{|c|}{$\begin{array}{c}90 \text { day mortality, } \mathbf{n} \\
(\%)\end{array}$} & \multicolumn{2}{|c|}{$\begin{array}{c}\text { Other mortality time- } \\
\text { points, } n(\%)\end{array}$} \\
\hline & & $\begin{array}{c}\text { Group } \\
2\end{array}$ & Group 1 & Group 2 & $\begin{array}{c}\text { Group } \\
1\end{array}$ & $\begin{array}{c}\text { Group } \\
2\end{array}$ & $\begin{array}{c}\text { Group } \\
1\end{array}$ & $\begin{array}{c}\text { Group } \\
2\end{array}$ & Group 1 & Group 2 \\
\hline \multicolumn{11}{|c|}{ Randomized trials } \\
\hline Moore 1994 ${ }^{21}$ & NR & NR & $1(2)$ & $2(4)$ & NR & NR & NR & NR & NR & NR \\
\hline Mendez $1997^{24}$ & NR & NR & NR & NR & NR & NR & NR & NR & $1(4.5)^{\mathrm{a}}$ & $1(5)^{\mathrm{a}}$ \\
\hline Garrel $2003^{25}$ & NR & $\mathrm{NR}$ & NR & NR & NR & NR & NR & NR & $12(63)^{a}$ & $2(13)^{a}$ \\
\hline $\begin{array}{l}\text { Falcao de Arrud } \\
2004^{26}\end{array}$ & & NR & $0(0)$ & $0(0)$ & NR & NR & NR & NR & NR & NR \\
\hline Peake $2014^{17}$ & & $9(16)$ & 10 (19) & $14(27)$ & $11(20)$ & $18(33)$ & $11(20)$ & $20(37)$ & $77(4.5)^{b}$ & $68(5.6)^{b}$ \\
\hline $\begin{array}{l}\text { TARGET } \\
\text { Investigators } 201\end{array}$ & & NR & $\begin{array}{l}468 \\
(23.8) \\
\end{array}$ & $\begin{array}{l}470 \\
(23.7) \\
\end{array}$ & $\begin{array}{l}450 \\
(22.9) \\
\end{array}$ & $\begin{array}{l}455 \\
(23.0) \\
\end{array}$ & $\begin{array}{l}523 \\
(26.8) \\
\end{array}$ & $\begin{array}{l}505 \\
(25.7) \\
\end{array}$ & NR & NR \\
\hline \multicolumn{11}{|c|}{ Non-randomized trials } \\
\hline Buonpane $1989^{31}$ & $0(0)$ & & $0(0)$ & & NR & & NR & & NR & \\
\hline Dickerson $2002^{18}$ & NR & NR & NR & NR & NR & NR & NR & NR & $1(8)^{\mathrm{a}}$ & $0(0)^{a}$ \\
\hline Ravasco $2003^{32}$ & $N R$ & & $24(55)$ & & NR & & NR & & NR & \\
\hline Farber $2005^{29}$ & NR & $N R$ & NR & NR & NR & NR & NR & NR & $1(6)^{\mathrm{a}}$ & $2(10)^{a}$ \\
\hline Soguel $^{d} 2008^{\frac{19}{9}}$ & $0(0)$ & $1(5)$ & $1(5)$ & $1(5)$ & NR & NR & NR & $N R$ & NR & NR \\
\hline Shields $2015^{33}$ & $5(100)$ & & NR & & NR & & NR & & NR & \\
\hline
\end{tabular}

ICU, Intensive Care Unit; ITT, Intention to treat; NR, not reported. Data are reported as mean (SD) unless otherwise stated. Group 1 received the highest calorie delivery

${ }^{\text {a }}$ Time point unclear

${ }^{\mathrm{b}}$ Mean (standard error) duration of survival, days

'Patient population included both burns and trauma patients. Data presented on burns subgroup only.

\begin{tabular}{|c|c|c|c|c|c|c|}
\hline \multirow{2}{*}{ Author, year } & \multicolumn{2}{|c|}{ Juration of MV, days } & \multicolumn{2}{|c|}{$\mathrm{CO}_{2}$ production, $\mathrm{ml} / \mathrm{min}$} & \multicolumn{2}{|c|}{$\mathrm{O}_{2}$ consumption, $\mathrm{ml} / \mathrm{min}$} \\
\hline & Group 1 & Group 2 & Group 1 & Group 2 & Group 1 & Group 2 \\
\hline \multicolumn{7}{|c|}{ Randomized trials } \\
\hline $\begin{array}{l}\text { Van den } \\
1994^{22}\end{array}$ & NR & NR & $\begin{array}{l}\text { MV } 0.225(0.007) \\
1 / \min ^{a} \\
\text { Weaning } 0.231 \\
(0.011) \mathrm{l} / \mathrm{min}^{\mathrm{a}}\end{array}$ & $\begin{array}{l}\mathrm{MV} 0.218(0.013) \\
\mathrm{l} / \mathrm{min}^{\mathrm{a}} \\
\text { Weaning } 0.177 \\
(0.010) \mathrm{I} / \mathrm{min}^{\mathrm{a}}\end{array}$ & $\begin{array}{l}\text { MV } 0.225(0.008) \\
1 / \min ^{a} \\
\text { Weaning } 0.271 \\
(0.013) \mathrm{l} / \mathrm{min}^{\mathrm{a}}\end{array}$ & $\begin{array}{l}\text { MV } 0.199(0.011) \\
1 / \min ^{a} \\
\text { Weaning } 0.244 \\
(0.010) \mathrm{l} / \mathrm{min}^{\mathrm{a}}\end{array}$ \\
\hline Moore $1994^{21}$ & $1.9(0.4)^{\mathrm{a}}$ & $5.3(2.9)^{\mathrm{a}}$ & NR & NR & NR & NR \\
\hline Long $1995^{23}$ & NR & NR & $\begin{array}{l}27.64 \quad[3.76] \quad \% \\
\text { from glucose }\end{array}$ & $\begin{array}{l}32.45 \quad[3.36] \quad \% \\
\text { from glucose }{ }^{a}\end{array}$ & NR & NR \\
\hline Garrel $2003^{25}$ & $22(10)$ & $24(11)$ & NR & NR & NR & NR \\
\hline
\end{tabular}

This article is protected by copyright. All rights reserved. 


\begin{tabular}{|c|c|c|c|c|c|c|}
\hline $\begin{array}{l}\text { Falcao de } \\
\text { Arruda } 2004^{26}\end{array}$ & $21(16.2)^{b}$ & $7.5(4.5)^{b}$ & NR & NR & NR & NR \\
\hline Peake $2014^{17}$ & $\begin{array}{l}16.5 \\
(16.4)^{\mathrm{c}, \mathrm{d}}\end{array}$ & $\begin{array}{l}14.8 \\
(19.5)^{c, d}\end{array}$ & NR & NR & NR & NR \\
\hline $\begin{array}{l}\text { TARGET } \\
\text { Investigators } 2018^{12}\end{array}$ & $\begin{array}{l}15 \\
(18.5)^{c, d}\end{array}$ & $\begin{array}{l}15 \\
(18.5)^{c, d}\end{array}$ & NR & NR & NR & NR \\
\hline \multicolumn{7}{|c|}{ Non-randomized trials } \\
\hline $\begin{array}{l}\text { Van den } \\
1988^{30}\end{array}$ & $12-38^{e}$ & $12-38^{\mathrm{e}}$ & $\begin{array}{ll}136 \\
\mathrm{ml} / \mathrm{min} / \mathrm{m}^{2}\end{array}$ & $\begin{array}{l}116 \\
\mathrm{ml} / \mathrm{min} / \mathrm{m}^{2}\end{array}$ & $\begin{array}{l}170(32) \\
\mathrm{ml} / \mathrm{min} / \mathrm{m}^{2}\end{array}$ & $\begin{array}{l}158(27) \\
\mathrm{ml} / \mathrm{min} / \mathrm{m}^{2}\end{array}$ \\
\hline Cerra $1989^{28}$ & NR & NR & $180(25)$ & $182(25)$ & $228(30)$ & $237(27)$ \\
\hline Dickerson $2002^{18}$ & $\begin{array}{l}23.7 \\
(16.6)\end{array}$ & $\begin{array}{l}15.9 \\
(10.8)\end{array}$ & NR & NR & NR & NR \\
\hline Farber $2005^{29}$ & $24(17)$ & $27(18)$ & NR & NR & NR & NR \\
\hline Soguel $^{f} 2008^{19}$ & $7.2(6.7)$ & $6.1(7.1)$ & NR & NR & NR & NR \\
\hline
\end{tabular}

IQR, interquartile range; NS, not specified; MV, mechanical ventilation; I/m, liters per minute; NR, not reported; temp, temperature; SEM, standard error of the mean; $\mathrm{ml} / \mathrm{min} / \mathrm{m}^{2}$, milliliters per minute; VFD, ventilator free days. Data are reported as mean (SD) unless otherwise stated. Group 1 received the highest calorie delivery.

${ }^{a}$ Mean (standard error of the mean)

${ }^{b}$ Median (range) converted to mean (SD)

${ }^{c}$ Ventilator free days to day 28

d Median (interquartile range) converted to mean (SD)

e Range

f Patient population included both burns and trauma patients. Data presented on burns subgroup only.

Cerra $1989^{28}$ also included a third arm for which the mean $\mathrm{CO}_{2}$ production was $171(22) \mathrm{ml} / \mathrm{min}$ and the mean $\mathrm{O}_{2}$ consumption was 198

(28) $\mathrm{ml} / \mathrm{min}$.

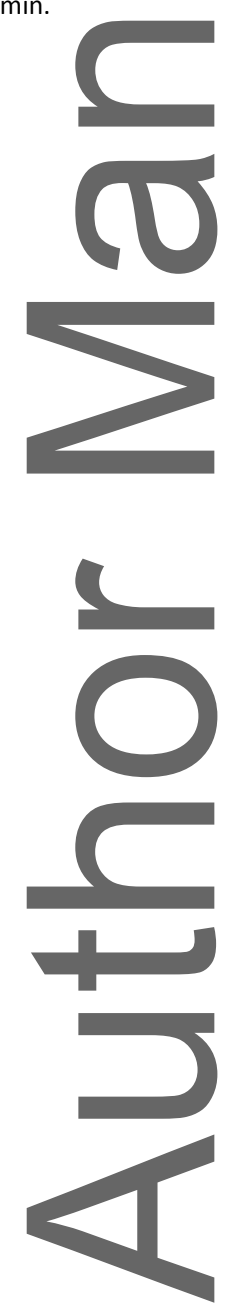


Table 5. Infectious complications

\begin{tabular}{|c|c|c|c|c|c|c|}
\hline \multirow[t]{2}{*}{ Author, year } & \multicolumn{2}{|c|}{ Total infections, n (\%) } & \multicolumn{2}{|c|}{ Pneumonia, n (\%) } & \multicolumn{2}{|c|}{ Bacteremia, n (\%) } \\
\hline & Group 1 & Group 2 & Group 1 & Group 2 & Group 1 & Group 2 \\
\hline \multicolumn{7}{|c|}{ Randomized trials } \\
\hline Moore $1994^{21}$ & NR & NR & $4(8)$ & $4(8)$ & $2(4)$ & $4(8)$ \\
\hline Mendez $1997^{24}$ & $19(86)$ & $12(57)$ & $16(73)$ & $11(52)$ & $6(27)$ & $7(33)$ \\
\hline Garrel $2003^{25}$ & NR & NR & NR & $\mathrm{NR}$ & $10(45)$ & $7(37)$ \\
\hline Falcao de Arruda $2004^{26}$ & $10(100)$ & $5(50)$ & NR & NR & $\mathrm{NR}$ & NR \\
\hline TARGET Investigators $2018^{12}$ & NR & NR & NR & NR & $228(11.6)$ & $221(11.1)$ \\
\hline \multicolumn{7}{|c|}{ Non-randomized trials } \\
\hline Dickerson $2002^{18}$ & NR & NR & $8(67)$ & $12(43)$ & NR & NR \\
\hline Farber $2005^{29}$ & NR & NR & $2(12)$ & $11(52)$ & $15(88)$ & $17(81)$ \\
\hline Soguel $^{\mathrm{a}} 2008^{19}$ & $0.8(0.5)$ & $0.6(0.6)$ & NR & NR & NR & NR \\
\hline
\end{tabular}

NR, Not reported. Data are reported as mean (standard deviation) unless otherwise stated. Group 1 received the highest calorie delivery

${ }^{a}$ Patient population included both burns and trauma patients. Data presented on burns subgroup only.

Table 6. Blood glucose control

\begin{tabular}{|c|c|c|c|c|c|c|}
\hline \multirow[t]{2}{*}{ Author, year } & \multicolumn{2}{|c|}{ Daily BGL, mmol/L } & \multicolumn{2}{|c|}{ Hyperglycemia, n (\%) } & \multicolumn{2}{|c|}{ Total insulin dose, IU } \\
\hline & Group 1 & Group 2 & Group 1 & Group 2 & Group 1 & Group 2 \\
\hline \multicolumn{7}{|c|}{ Randomized trials } \\
\hline Garrel $2003^{25}$ & $8.9(1.8)$ & $8.6(1.4)$ & NR & NR & $38(24)$ & $42(29)$ \\
\hline Peake $2014^{17}$ & $12.4(3.9)$ & $12.0(3.9)$ & NR & NR & $55(22-131)^{a}$ & $43(24-67)^{\mathrm{a}}$ \\
\hline $\begin{array}{l}\text { TARGET } \\
\text { Investigators } 2018^{12}\end{array}$ & NR & NR & $\begin{array}{l}\text { Highest BGL: } 12.5 \\
(10.3-15.4) \mathrm{mg} / \mathrm{dl}^{\mathrm{a}}\end{array}$ & $\begin{array}{l}\text { Highest BGL: } 11.8 \text { (9.7- } \\
14.5) \mathrm{mg} / \mathrm{dl}^{\mathrm{a}}\end{array}$ & $3.0(0-41.8)^{\mathrm{ab}}$ & $0(0-30.6)^{a b}$ \\
\hline \multicolumn{7}{|c|}{ Non-randomized trials } \\
\hline Buonpane $1989^{31}$ & NR & & $3(25)$ & & NR & \\
\hline Soguel $^{\mathrm{C}} 2008^{19}$ & NR & NR & NR & NR & $41(34)$ & $29(48)$ \\
\hline
\end{tabular}

BGL, Blood glucose level, IU, International units. Data are reported as mean (SD) unless otherwise stated. Group 1 received the highest calorie delivery.

${ }^{\text {a }}$ Median (interquartile range)

${ }^{\mathrm{b}}$ Daily insulin dose

${ }^{c}$ Patient population included both burns and trauma patients. Data presented on burns subgroup only.

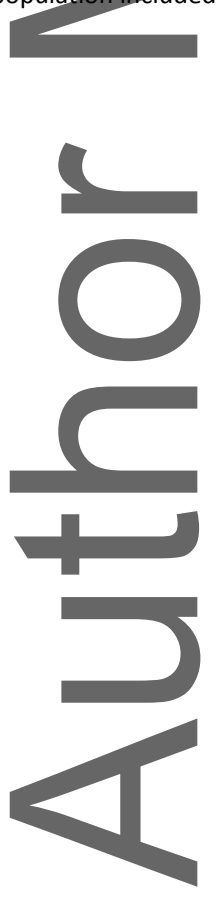




\section{Figure Legend:}

Figure 1. Consort diagram of included trials

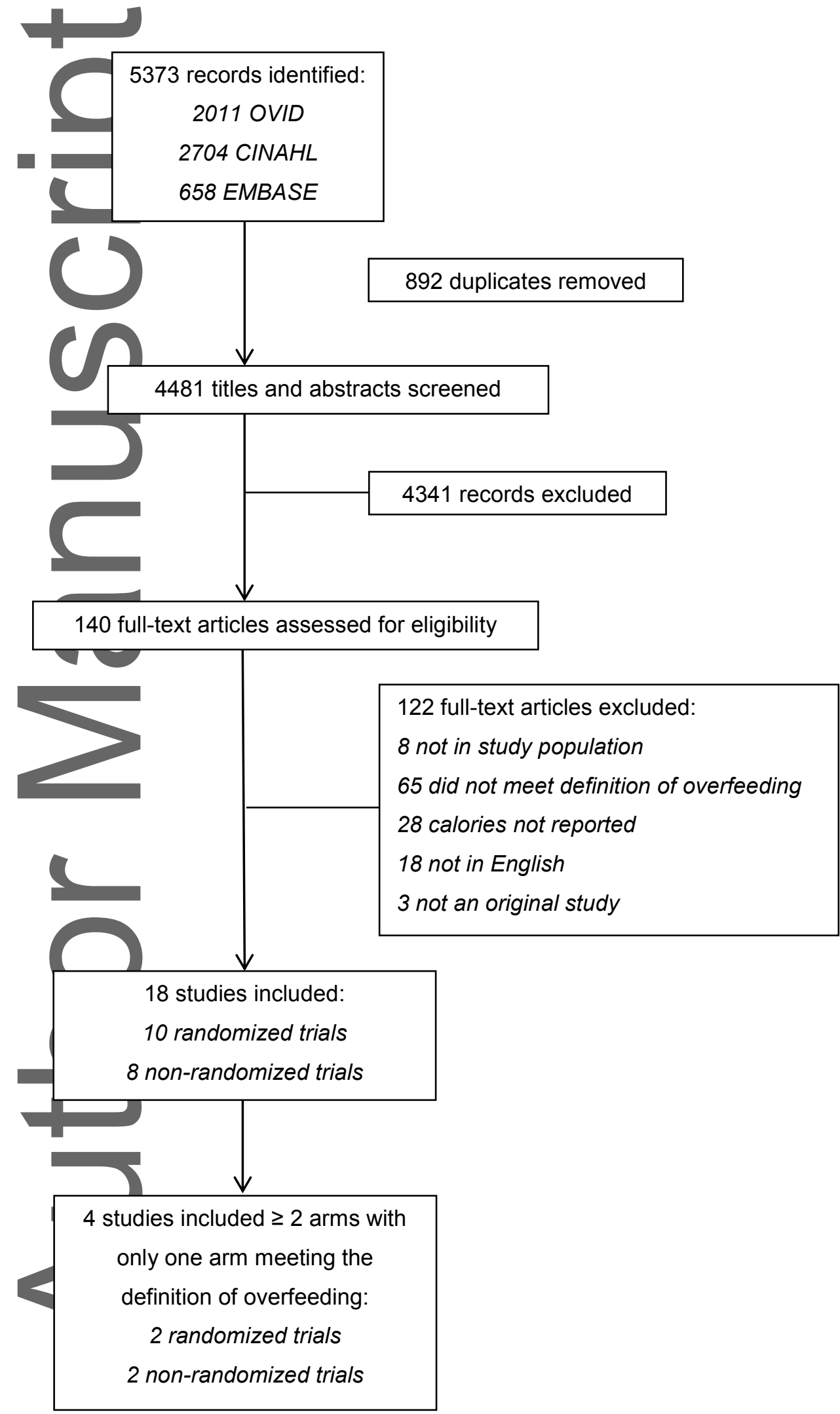




\section{University Library}

\section{- M M N E R VA A gateway to Melbourne's research publications}

Minerva Access is the Institutional Repository of The University of Melbourne

Author/s:

Chapple, L-AS;Weinel, L;Ridley, EJ;Jones, D;Chapman, MJ;Peake, SL

Title:

Clinical Sequelae From Overfeeding in Enterally Fed Critically III Adults: Where Is the Evidence?

Date:

2019-11-17

Citation:

Chapple, L. -A. S., Weinel, L., Ridley, E. J., Jones, D., Chapman, M. J. \& Peake, S. L. (2019). Clinical Sequelae From Overfeeding in Enterally Fed Critically III Adults: Where Is the Evidence? JOURNAL OF PARENTERAL AND ENTERAL NUTRITION, 44 (6), pp.980-991. https://doi.org/10.1002/jpen.1740.

Persistent Link:

http://hdl.handle.net/11343/286627 